\title{
"Facts Available" Dumping Allegations: When Will Foreign Firms Cooperate in Antidumping Petitions?
}

\author{
Michael O. Moore ${ }^{a}$ \\ Associate Professor of Economics and International Affairs
}

29 April 2002

\begin{abstract}
Foreign firms accused of dumping in the WTO system may face punitive duties if they do not cooperate with domestic investigative authorities. These punitive tariffs are typically based on the allegations of domestic firms filing the antidumping petition-so-called "facts available" dumping margins. This paper analyzes a game between two Bertrand Nash competitors: a) domestic petitioner and b) a foreign respondent, as well as an administering authority. Foreign firm cooperation will depend on the interplay between compliance costs and the allegations of the domestic competitor. The final tariff and degree of cooperation will depend on the level of compliance costs chosen by the domestic authority.
\end{abstract}

JEL classification: F13, K23

Keywords: antidumping, commercial policy, facts-available dumping margin

${ }^{\text {a }}$ Department of Economics and the Elliott School

George Washington University

$2201 \mathrm{G}$ St. NW

Washington, DC 20052

email: mom@gwu.edu

voice: +202-994-6157

fax: +202-994-6147

I wish to thank Steve Suranovic and participants at the Midwest International Economics Association meetings for very helpful comments on this paper. 


\section{Introduction}

Antidumping is one of the most frequently researched areas of trade policy over the last twenty years. This reflects the fact that antidumping duties are the most common form of import relief under the General Agreement on Tariffs and Trade (GATT) and the current World Trade Organization (WTO) system. Economists have analyzed many aspects of antidumping, both theoretical and empirical. ${ }^{1}$

One area of importance has not received such scrutiny in the economics literature. WTO rules (and the GATT before it) allow governments to use dumping margin allegations provided by the domestic petitioners in assessing tariffs on foreign firms that do not cooperate in "unfair trade" investigation. In particular, the Antidumping Agreement concluded in the Uruguay Round of trade negotiations states that:

"In cases in which an interested party refuses access to, or otherwise does not provide, necessary information within a reasonable time or significantly impedes the investigation, [decisions] may be made on the basis of facts available." 2

An annex to the agreement adds that the authorities will be free to make determinations based on facts "including those contained in the application for the initiation of the investigation by the

${ }^{1}$ The literature is too large to fully present here. Theoretical analyses include Brander and Krugman (1983), Ethier (1982), Hoekman and Leidy (1993) Staiger and Wolack (1996) and Hartigan (1999, and 2000). Empirical studies include Blonigen (2000), Devault (1993), Finger Hall and Nelson (1982), Kelley and Mokre (1998), Hansen and Prusa (1997), Liebman (2001), Messerlin (1989), and Moore (1992).

${ }^{2}$ Antidumping Agreement (1994), p 154. 
domestic industry."3

The justification for this provision is simple. The calculated dumping margin normally is based on a comparison of the export price with either the price charged in the exporter's home market or its production costs. However, foreign prices or costs are typically privately-held information of the exporter so that foreign firms need some incentive to cooperate in an investigation. This incentive in practice has been provided by the potential use of the domestic firm's allegations (called "best-information available," or BIA, under the GATT rules) about foreign firms' dumping margin. Since the domestic firm has an obvious incentive to overstate the dumping margin when laying out its case, the exporter faces the possibility of very high duties if it does not cooperate.

Critics of this system's application in the pre-WTO US system have noted that the average dumping margin when BIA was used was much higher than calculated rates. Baldwin and Moore (1991) report that for the period between 1980 and 1990, the average final dumping margin imposed by the Department of Commerce (DOC), the relevant US authority, using BIA methods was $67 \%$ (36 cases) while the average duty based on foreign-firm provided information was only $28 \%$ (188 cases). One of the main problems in the US, so the critics argued, was that the Department of Commerce often made compliance very difficult for foreign companies (including 200-page questionnaires, tight deadlines, requirements to report data using US-style accounting techniques, and on-site investigations of all records by US investigators). ${ }^{4}$ In

\footnotetext{
${ }^{3}$ Antidumping Agreement, Annex II, p. 168.
}

${ }^{4}$ See Murray (1991), Palmeter (1991) and Finger and Artis (1993) for discussion of these and other problems. 
addition, if foreign firms were found by the DOC to be only "partially-cooperative," all information provided by the firms could be thrown out, with BIA used in its place. After considering these procedures, many critics saw the BIA provisions as a means by which domestic firms could use the system, not to elicit truthful announcements about foreign costs and pricing behavior, but instead to bring duties on foreign firms far in excess of the true dumping margin.

Supporters argue that this "stick" is the only way to achieve compliance. Stewart (1991) and Mastel (1998) note that administrators determining dumping margins are confronted with the problem that their decision in principle relies largely on data provided by the foreign firm. Without BIA, foreign firms could thwart the investigation simply by withholding data so that these provisions are the only way for an administering authority to obtain the true level of dumping. Finally, supporters in the US note that the DOC does not always use BIA so that it is unfair to allege that BIA margins are simply a means to force high tariffs onto innocent foreign firms. Indeed, information provided by Baldwin and Moore is consistent with this: only sixteen percent of final dumping margins assessed during the 1980s in the US used BIA information.

While complaints about BIA led to some reform of the process in the Uruguay Round, the use of domestic allegations in antidumping duty calculation remains an important part of the system. The most notable reform was that "reasonable attempts" to fulfill the information requests must be recognized. However, the domestic administering authorities still may use petitioners' allegations when foreign firms do no cooperate. ${ }^{5}$

US law implementing the Uruguay Round reflected these changes. One particularly

${ }^{5}$ See Antidumping Agreement (1994) for more details. 
cosmetic change was that the DOC no longer uses the term "best-information-available" but instead "facts available". Yet the DOC's new regulations made clear that the use of "adverse inferences" could be justified if the foreign respondent was perceived as deliberately uncooperative, an approach fully supported by the Congress and the President. In addition, the Department of Commerce continues to use margins calculated using particular now-prohibited BIA methods under the GATT system in the recently-inaugurated US "sunset review" process, which was designed to evaluate whether antidumping orders should remain in place five years after their initiation (Moore, 1999).

Certainly the "stick" of "facts available" data remains a very significant threat. In recent cold-rolled steel antidumping cases, the DOC used "facts-available" in all but two of the cases for the final dumping margin. ${ }^{6}$ The margins (which ranged from $46 \%$ to $64 \%$ for Brazil, $53 \%$ for Japan, and $109 \%$ to $163 \%$ for Slovakia) yielded significantly lowered imports from the targeted countries. ${ }^{7}$

Despite the importance of BIA in the administration of antidumping law, no systematic study of the use of BIA appears in the economics literature. Economists analyzing the US antidumping process typically argue that since the Commerce Department almost always finds a positive dumping margin in its investigations (nearly $95 \%$ of cases), then the focus should be on the injury decisions by the US International Trade Commission. But this ignores the fact that the DOC determines the specific duty level, often using "facts-available" margins, and thereby the

${ }^{6}$ The only two cases not using "facts-available" were for China and Russia, both of which are designated "non-market-economies" and thus are subject to entirely different procedures.

${ }^{7}$ Federal Register, various issues. 
restrictiveness of the import regime.

This paper will begin to fill this gap. A number of questions will be addressed. First, if the use of BIA is credible (which it surely must be, at least in the US given the history of AD administration), why do foreign firms still sometimes choose not to cooperate? Second, if domestic firms know that an administering authority might use their allegations, why not always announce alleged foreign costs high enough to eliminate all imports? Is it always in the domestic firm's interests to force foreigners not to cooperate and thereby be "punished" with BIA margins? Finally, what is the administering authority's optimal decision concerning compliance costs faced by foreign firms?

We will address this in a Bertrand-Nash model in which a foreign firm endogenously chooses whether to cooperate in an antidumping investigation. ${ }^{8}$ Its choice will depend on the domestic firm's announcement about the alleged foreign dumping margin while the authority sets the costs of the foreign firm complying with its investigation. The approach in this model is similar to Prusa (1992) who models the choice of firms between withdrawing an antidumping petition or pursuing it to its final conclusion. However, in this model, we approach an earlier part of the antidumping process, in particular, whether the foreign firm will cooperate with the investigation in the first place.

Three types of behavior by the domestic authority will be addressed. We first assume that the authority sets an unchanging level of compliance cost. We then analyze the outcome when the authority chooses the compliance cost strategically but is indifferent to the impact of

${ }^{8}$ Another related approach is that of Moore and Suranovic (1992) who also explicitly allow foreign firms to choose their path of protection. 
the duty on domestic consumers. Finally, we assume that the authority cares about both consumer and producer welfare. Each of these scenarios yields a different combination of compliance cost, tariff rate, and frequency of foreign firm cooperation.

We focus on aspects of the relationship cited by critics, i.e., that "facts-available" information is a means for domestic firms to achieve higher duties. We do not consider how the authority might use "facts-available" to elicit accurate information about foreign costs. While this latter issue is important, it is best analyzed using a game between the authority and foreign firm with asymmetric information. This would be a useful extension to the present work. ${ }^{9}$

\section{Institutional Context and Modeling Framework}

Under the WTO system, domestic import-competing firms may petition their government to impose antidumping duties on foreign firms' exports. These petitions must include an allegation about the extent to which foreign firms are selling in the home market below "normal value." The government may decide to impose antidumping duties if two criteria are met. First, it must find that foreign firms are selling in the domestic market below "normal value," defined as either production cost or home market price. Second, an investigation must determine that the dumped imports have caused "material injury" to a domestic industry producing a "like product."

In the US, administration of this system is broken up into two parts. The US Department of Commerce undertakes investigations of dumping margin and hence must consider information

\footnotetext{
${ }^{9}$ Kohler and Moore (2001) use an incentive mechanism framework to show how a domestic authority can elicit truthful information from domestic firms about their actual level of injury in antidumping petitions.
} 
about foreign firms' sales and production data for the narrowly-defined product in the antidumping petition. The DOC will make its determination after eliciting detailed information about the particular product from the foreign firms. In a parallel process, the US International Trade Commission must decide whether the dumped imports have caused material injury. Only if both agencies rule affirmatively can a duty be placed on foreign products.

Other signatories to the WTO have similar two-part systems. In essence, signatory nations must make a determination about the dumping margin, which is based on foreign firm behavior (or allegations thereof), and a second part where final decisions are made about the level of injury and, in some jurisdictions, whether or not imposing duties are in the "public interest." ${ }^{10}$

This paper will focus on the first part of this process - the dumping margin investigation - and will keep the final decision on the level of the antidumping duty and whether or not to impose duties in the background. We assume therefore that there is an exogenous probability of a successful antidumping petition and an exogenously determined antidumping duty. Thus, we are not analyzing the decision of whether or not to finally impose duties or the overall government problem when determining the structure of the antidumping mechanism. Instead, we are looking at the incentives created for foreign firms to cooperate or not in the dumping margin investigation.

The relationships are modeled as a three-stage game among an administering authority, a domestic firm, and a foreign firm:

\footnotetext{
${ }^{10}$ For example, the European Union requires final dumping duties to be approved by the Council of Ministers.
} 


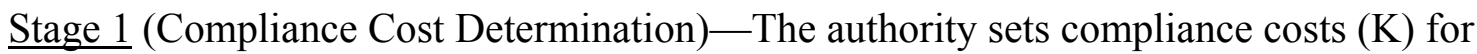
the foreign firm in "cooperative" antidumping investigations.

$\underline{\text { Stage } 2}$ (Domestic Firm Dumping Allegation)----The domestic firm chooses the level of alleged foreign dumping through its selection of $t_{\mathrm{f}}$, the so-called "facts available tariff." In the event that the foreign firm does not cooperate, this will be the level of tariff imposed on the foreign firm if the petition is won by the domestic firm.

$\underline{\text { Stage } 3}$ (Foreign Cooperation Decision)---The foreign firm decides whether to cooperate in the antidumping petition. If it cooperates, an antidumping duty $\left(t_{A}\right)$ is imposed with some positive probability $(\gamma)$, at the "material injury" stage of the antidumping process. If it does not cooperate, the foreign firm will face a duty $\left(t_{\mathrm{F}}\right)$ based on the domestic firm's allegation with some positive probability $(\mu)$.

Domestic and foreign firms are assumed to be Bertrand-Nash competitors. Their outputs are imperfect substitutes in the domestic market and are assumed to be produced using constant marginal-cost production technologies.

Three distinct sets of Nash equilibrium profit levels are possible under this structure. They are: $\left(\pi *_{\mathrm{F}}, \pi_{\mathrm{F}}\right),\left(\pi *_{\mathrm{A}}, \pi_{\mathrm{A}}\right)$, and $\left(\pi *_{\mathrm{N}}, \pi_{\mathrm{N}}\right)^{11}$, which represent foreign and domestic profit under non-cooperation (with the tariff equal to domestic firm allegations $\left(t_{\mathrm{F}}\right)$ ), the antidumping

\footnotetext{
${ }^{11}$ Starred variables refer to foreign variables.
} 
duty (with the tariff equal to the antidumping tariff $\left(\mathrm{t}_{\mathrm{A}}\right)$ ) and profit under the free-trade BertrandNash outcome, respectively. We also define a "prohibitive"tariff which we call T — any tariff imposed beyond this level will choke off all imports.

\section{Foreign firm cooperation:}

Outcome (probability) Domestic profit Free-trade $(\gamma)$

AD duty $(1-\gamma)$

$$
\pi_{\mathrm{N}}
$$$$
\pi_{\mathrm{A}}
$$

Foreign profit Tarifflevel

$\pi *_{\mathrm{N}}$

$\pi *_{\mathrm{A}}$ $\mathrm{t}=0$

$\mathrm{t}=\mathrm{t}_{\mathrm{A}}$

$\mathrm{t}=0$

$\mathrm{t}=\mathrm{t}_{\mathrm{F}}$
Price pair

$\mathrm{P}_{\mathrm{N}}, \mathrm{P}^{*}{ }_{\mathrm{N}}$

$\mathrm{P}_{\mathrm{A}}, \mathrm{P}_{\mathrm{A}}^{*}+\mathrm{t}_{\mathrm{A}}$

\section{Foreign firm non-cooperation}

Free-trade $(\mu)$

Facts-available $(1-\mu)$

$\pi_{\mathrm{N}}$

$\pi_{\mathrm{F}}$ $\pi *_{N}$

$\pi^{*}{ }_{\mathrm{F}}$
$\mathrm{P}_{\mathrm{N}}, \mathrm{P}^{*}{ }_{\mathrm{N}}$ $\mathrm{P}_{\mathrm{F}}, \mathrm{P}_{\mathrm{F}}^{*}+\mathrm{t}_{\mathrm{F}}$

The domestic firm's announcement of $t_{\mathrm{F}}$ will affect the foreign firm's decision to cooperate as well as the profits under non-cooperation $\left(\pi_{\mathrm{F}}, \pi *_{\mathrm{F}}\right)$. But it should be noted that the other profit levels are not dependent on the domestic firm's announcement. The free-trade Nash outcome profit level $\left(\pi_{\mathrm{N}}\right)$ is independent of $t_{F}$ (as well as $\mu, \gamma$ and $t_{A}$ ) and depends only on the interaction between the firms when they reach that node of the game. The antidumping duty outcome $\left(\pi_{\mathrm{A}}\right)$ is likewise determined by the Nash competition between the two firms, when the (exogenously-determined) antidumping tariff $\left(\mathrm{t}_{\mathrm{A}}\right)$ is included.

We assume that the foreign firm's optimal free-trade pricing strategy is to sell in the domestic market below its own home market price. Thus, while we are analyzing a situation of imperfect competition where the domestic and foreign firms are both receiving positive profits, there is "dumping" from a legal point of view. Thus, these probabilities are not the chance that a positive dumping margin will be found by, for example, the US Commerce Department . Instead, the uncertainty arises out of the possibility that "material injury" may or may not be found at a latter stage of the investigation. 
The model is solved by backward induction. The foreign firm will cooperate if the expected profits under cooperation are greater than under non-cooperation. ${ }^{12}$ The domestic firm chooses $t_{F}$ knowing the decision rule of the foreign firm. If it chooses $t_{F}$ too high, then the foreign firm will cooperate and it is possible that the foreign firm will face no duties if it wins the case. If $t_{F}$ is set too low, then the foreign firm may decide not to cooperate and may get off "easy" with a low tariff.

The administering authority knows the structure of the problems solved by the other agents when it makes its own decisions. We assume that its sole decision variable is the compliance costs (K). The domestic authority's decision variable, compliance costs, may seem overly narrow. One might argue that the probabilities of imposing the duties and the antidumping duties should be endogenously chosen by the authority. However, allowing the authority to choose the probabilities of a successful petition $\mu$ and $\gamma$ or the antidumping tariff $\left(t_{A}\right)$ would alter the level of expected profits available to the firms but would not alter the basic issue that the foreign firm must compare the relative profits between the two paths when deciding whether to cooperate. Likewise, the authority could alter the specific payoff to the domestic firm by choosing the antidumping duty. Regardless of whether the probabilities and antidumping tariff are endogenous, the domestic firm must still must consider the impact on the foreign firm's choice about cooperation when announcing its dumping margin allegation, regardless of the specific level of the antidumping duty $\left(t_{A}\right)$. Thus, we simplify the analysis by treating these as an exogenous variables and focus the domestic authority's decision exclusively

\footnotetext{
${ }^{12}$ We do not allow for the game to end with a negotiated settlement as in Prusa (1992).
} 
on the compliance costs.

The structure of the game is depicted in extensive form in Figure 1.

\section{Stage 3: Foreign firm decision}

Suppose that when a (representative) foreign firm cooperates with the investigation, it must incur (constant) compliance costs equal to K. These compliance costs are those associated with providing information to the administering authority, legal fees, etc. The price pair $\left(\mathrm{P}^{*}{ }_{\mathrm{N}}\right.$, $\mathrm{P}_{\mathrm{N}}$ ) is the free-trade Nash couple. If the antidumping duty is imposed, the foreign price will of course be equal to the resulting foreign Nash price plus the antidumping duty: $\mathrm{P}{ }_{\mathrm{A}}\left(\mathrm{t}_{\mathrm{A}}\right)+\mathrm{t}_{\mathrm{A}} \cdot{ }^{13}$ The domestic Nash price under the antidumping duty equals $\mathrm{P}_{\mathrm{A}}\left(\mathrm{t}_{\mathrm{A}}\right)$.

The expected foreign profits under cooperation are therefore equal to ${ }^{14}$

$$
\begin{gathered}
\mathrm{E}_{\gamma}\left(\pi *_{\mathrm{COOP}}\right)=\gamma\left[\left(\mathrm{P}^{*}{ }_{\mathrm{N}}-\mathrm{C}^{*}\right) \cdot \mathrm{Q}^{*}{ }_{\mathrm{N}}\right] \\
+(1-\gamma)\left[\left(\mathrm{P}^{*}{ }_{\mathrm{A}}-\mathrm{C}^{*}\right) \cdot \mathrm{Q}^{*}{ }_{\mathrm{A}}\right]-\mathrm{K} \\
=\gamma \pi^{*}{ }_{\mathrm{N}}+(1-\gamma) \pi^{*}{ }_{\mathrm{A}}-\mathrm{K}
\end{gathered}
$$

where $\mathrm{Q}^{*}{ }_{\mathrm{N}}=\mathrm{Q}^{*}\left(\mathrm{P}^{*}{ }_{\mathrm{N}}, \mathrm{P}_{\mathrm{N}}\right)$ and $\mathrm{Q}^{*}{ }_{\mathrm{A}}=\mathrm{Q}^{*}\left(\mathrm{P}^{*}{ }_{\mathrm{A}}, \mathrm{P}_{\mathrm{A}}\right)$, i.e., the demand for foreign output under the free-trade and antidumping duty Nash equilibria, respectively. Foreign (constant) marginal production costs are given by $C^{*}$. Expression (1) can be either positive or negative, depending on the size of compliance costs.

${ }^{13}$ Tariffs are assumed to be specific.

${ }^{14}$ We assume that the foreign firm's home and export market are perfectly segmented. Thus, we ignore any interactions between pricing behavior in the two markets. 
If the firm does not cooperate, the administering authority uses the "facts available" provided by the domestic firm. Typically, this comes in the form of an announcement about foreign costs or home market sales price but these of course implicitly determine the resulting tariff placed on the foreign firm. In this model, therefore, the choice made by the domestic firm is the "facts-available" tariff under non-cooperation: $t_{\mathrm{F}}$.

The foreign firm knows this alleged level of its costs before it makes its decision about cooperation since it will be published in the original documents requesting an antidumping investigation. The resulting price charged by the non-cooperating foreign firm will be equal to the Nash price when the "facts available" duty is in force: $\mathrm{P}{ }_{\mathrm{F}}\left(\mathrm{t}_{\mathrm{F}}\right)+\mathrm{t}_{\mathrm{F}}$. The corresponding domestic Nash price is $\mathrm{P}_{\mathrm{F}}$.

The foreign firm will not bear any compliance costs if it does not cooperate but it does face sales determined by the dumping margin alleged by the domestic firm.. ${ }^{15}$

Expected foreign profits with no cooperation will be

$$
\begin{aligned}
\mathrm{E}_{\mu}\left(\pi{ }^{*}{ }_{\mathrm{NC}}\right)= & \left.\mu\left[\left(\mathrm{P}^{*}{ }_{\mathrm{N}}-\mathrm{C}^{*}\right) \cdot \mathrm{Q}^{*}{ }_{\mathrm{N},}\right]+(1-\mu)\left[\left(\mathrm{P}_{\mathrm{f}}^{*}\left(\mathrm{t}_{\mathrm{F}}\right)-\mathrm{C}^{*}\right) \cdot \mathrm{Q} *\left(\mathrm{P}_{\mathrm{f}} \mathrm{t}_{\mathrm{F}}\right)+\mathrm{t}_{\mathrm{F}}, \mathrm{P}_{\mathrm{f}}\right)\right] \\
& =\mu\left[\pi^{*}{ }_{\mathrm{N}}\right]+(1-\mu)\left[\pi_{\mathrm{f}}^{*}\right]
\end{aligned}
$$

The foreign firm will choose to cooperate if the expected profits of cooperation exceeds those of not cooperating:

${ }^{15}$ Firms will face certain legal costs at the latter "material injury" determination stage, regardless of whether they cooperate or not. Since these costs are likely invariant to the choice to cooperate or not, they are ignored in this analysis. 


$$
\mathrm{E}_{\gamma}\left(\pi *_{\mathrm{COOP}}\right)>\mathrm{E}_{\mu}\left(\pi *_{\mathrm{NC}}\right)
$$

or, equivalently, if:

$$
\mathrm{F}\left(\gamma, \mu, \mathrm{t}_{\mathrm{F}}\right) \equiv \gamma\left[\pi_{\mathrm{N}}^{*}\right]+(1-\gamma)\left[\pi_{\mathrm{A}}^{*}\right]-\mu\left[\pi_{\mathrm{N}}^{*}\right]-(1-\mu)\left[\pi_{\mathrm{A}}^{*}\right]>\mathrm{K}
$$

We will assume that the probability of the foreign firm winning the petition cannot be lower by cooperating than by withholding information: $\mu \leq \gamma$.

Assuming Nash behavior by the foreign firm, $\mathrm{F}(.,$.$) has the following property:$

$$
\frac{\partial F}{\partial t_{f}}=-\frac{\partial \pi_{f}^{*}}{\partial t_{f}}=-\left[\left(P_{f}^{*}-C^{*}\right) \cdot\left\{\frac{\partial Q *}{\partial P^{*}}\left(\frac{\partial P_{f}^{*}}{\partial t_{f}}+1\right)\right\}+Q^{*} \frac{\partial P_{f}^{*}}{\partial t_{f}}\right]
$$

Expression (5) in principle can be either positive or negative, given that own demand is decreasing in price. This ambiguity reflects the fact that while the foreign firm loses sales through the imposition of the tariff, a Bertrand competitor is able to raise its net price. In other words, the foreign reaction curve moves to the right in $\mathrm{P}-\mathrm{P}^{*}$ space which somewhat mitigates the lost sales. However, we will make the assumption that $\mathrm{dF} / \mathrm{dt}_{\mathrm{F}}$ is negative, i.e, that foreign profit will fall as a consequence of a tariff imposed on its sales.

It will be useful to implicitly define a breakeven level of alleged costs $\left[t^{*}{ }_{\mathrm{BE}}(\mathrm{K})\right]$ that makes the foreign firm indifferent between the two paths: 


$$
\phi\left(\mathrm{t}_{\mathrm{BE}}(\mathrm{K})\right)=\gamma\left[\pi_{\mathrm{N}}\right]+(1-\gamma)\left[\pi *_{\mathrm{A}}\right]-\mu\left[\pi *_{\mathrm{N}}\right]-(1-\mu)\left[\pi *_{\mathrm{f}}\right]-\mathrm{K}
$$

For any domestic dumping margin allegation such that $\mathrm{t}_{\mathrm{F}}<\mathrm{t}^{*}{ }_{\mathrm{BE}}(\mathrm{K})$, the foreign firm will choose non-cooperation.

Using the implicit function theorem, we have from (6):

$$
\frac{d{ }^{*} B E(K)}{d K}=-\frac{\partial \phi}{\partial K} / \frac{\partial \phi}{\partial t_{F}}=1 / \frac{d F\left(\gamma, t_{F}\right)}{d t_{F}}>0
$$

As long as foreign profits are falling in $\mathrm{t}_{\mathrm{F}}$, then an increase in the compliance costs of cooperation increases the level of announced "facts available" which would make the foreign firm indifferent between the two paths. Increasing the compliance costs thus means that the domestic firm could announce a higher value of $t_{F}$ and the foreign firm will still cooperate.

Figure 2 depicts the foreign firm's decision. $\mathrm{E}_{\gamma}\left(\pi *_{\mathrm{COOP}}\right)$ is a horizontal line since its value does not depend on the domestic firm's dumping allegation. The impact of an increase in the domestic firm's allegation about foreign dumping depends on the slope of $\pi *_{\mathrm{f}}$ which is negative given our assumption about $\mathrm{dF} / \mathrm{dt}_{\mathrm{F}}$. As $\mathrm{K}$ increases, then $\mathrm{t}^{*}{ }_{\mathrm{BE}}(\mathrm{K})$ will definitely rise. In addition, if the domestic firms announces any $t_{F}>t^{*}{ }_{B E}(K)$ then the foreign firm will choose to cooperate. For any $\mathrm{t}_{\mathrm{F}}<\mathrm{t}^{*}{ }_{\mathrm{BE}}(\mathrm{K})$ then the foreign firm will not cooperate.

For later use, we can also use Figure 2 to discuss the impact of the domestic firm alleging a prohibitive tariff (denoted $\mathrm{T}$ ) under non-cooperation. For any $t_{\mathrm{F}} \geq \mathrm{T}$, we will have $\pi_{\mathrm{F}}^{*}=0$ since the foreign firm will have no sales in the domestic market. Thus, $E_{\mu}\left(\pi *_{N C}(T)\right)=\mu\left[\pi^{*}{ }_{N}\right]$ 
$>0$ as long as there is a positive probability that it can win the case without cooperating. Note that if compliance costs rise sufficiently, then $\mathrm{E}_{\gamma}\left(\pi *_{\mathrm{COOP}}(\mathrm{K})\right)$ could fall below point A in Figure 2. In such a case, the "breakeven" tariff would not be well defined. The foreign firm would always find it more profitable not to cooperate and face the prohibitive tariff.

Before moving to the domestic firm's decision, it is worth pausing to note some further aspects of the foreign firm's decision. Suppose that a foreign firm knows with absolutely certainty that it would win a case at the final stage if it decides to cooperate but that a duty will definitely be imposed if it decides not to cooperate, i.e., $\gamma=1$ and $\mu=0$. Nonetheless, the foreign firm will not cooperate if the domestic firm announces a "facts-available" tariff which yields

$\mathrm{F}\left(0,1, \mathrm{t}_{\mathrm{F}}\right)=\pi *_{\mathrm{N}}-\pi *_{\mathrm{f}}<\mathrm{K}$. This is an example of "pure harassment"; the foreign firm will definitely win the litigation under cooperation but finds it too costly to pursue that option. Another way of expressing this is that cooperation would be guaranteed in this case only if compliance costs were zero.

Suppose instead that the foreign firm knows with absolutely certainty that it will lose the antidumping case under both paths so that $\mu=\gamma=0$. The only way that it will cooperate in this case is if its own profits are higher under cooperation: $F\left(0,0, t_{F}\right)=\pi *_{A}-\pi *_{f}>K$. Thus, its decision still will depend on the announcement of $t_{F}$ by the domestic firm. As we will see below, it could be that the domestic firm's profit would be higher under non-cooperation than with the (now certain) level of profits under the regular antidumping process. In that event, the domestic firm might set its alleged dumping margin low enough so that the foreign firm will find it more profitable not to cooperate, even though the foreign firm knows it will lose its case. 
In sum, the higher is the facts-available dumping allegation announced by the domestic firm, the more likely there will be cooperation. However, there is no way to insure cooperation for positive compliance costs, even if the foreign firm knows with certainty that it would win a case if it decides to cooperate. This analysis shows that the fact that foreign firms do not cooperate does not mean that they have something to hide-----the keys to their decision are compliance costs and the domestic firms allegations about dumping.

\section{Stage 2: Domestic firm decision.}

The (representative) domestic firm must makes its decision about the dumping margin it will allege (i.e., $\mathrm{t}_{\mathrm{F}}$ ) in the antidumping petition. It does this taking as given the level of compliance costs but anticipating the decision rule of the foreign firm in stage 3. Ultimately, the domestic firm would like to induce the foreign firm to follow the path which leads to the highest possible domestic profit level. As will be shown below, for some values of compliance costs, the domestic firm would rather have cooperation while for others, it would rather force the foreign firm to face the "facts-available" dumping margin.

We now turn to the domestic firm's preferred outcome. We assume that it also faces constant production costs. The expected domestic profits under cooperation is:

$$
\begin{aligned}
& \mathrm{E}_{\gamma}\left[\pi_{\mathrm{COOP}}\right]=\gamma\left[\left(\mathrm{P}_{\mathrm{N}}-\mathrm{C}\right) \cdot \mathrm{Q}\left(\mathrm{P}_{\mathrm{N}}, \mathrm{P}^{*}{ }_{\mathrm{N}}\right)\right] \\
& +(1-\gamma)\left[\left(\mathrm{P}_{\mathrm{A}}\left(\mathrm{t}_{\mathrm{A}}\right)+\mathrm{t}_{\mathrm{A}}-\mathrm{C}\right) \cdot \mathrm{Q}\left(\mathrm{P}_{\mathrm{A}},\left(\mathrm{t}_{\mathrm{A}}\right), \mathrm{P}^{*}{ }_{\mathrm{A}}\right)\right] \\
& \quad=\gamma \pi_{\mathrm{N}}+(1-\gamma) \pi_{\mathrm{A}}
\end{aligned}
$$

If the foreign firm does not cooperate, the domestic firm's expected profit equals

$$
\mathrm{E}_{\mu}\left[\pi_{\mathrm{NC}}\right]=\mu\left[\left(\mathrm{P}_{\mathrm{N}}-\mathrm{C}\right) \cdot \mathrm{Q}\left(\mathrm{P}_{\mathrm{N}}, \mathrm{P}_{\mathrm{N}}^{*}\right)\right]
$$




$$
\begin{aligned}
& +(1-\mu)\left[\left(\mathrm{P}_{\mathrm{f}}\left(\mathrm{t}_{\mathrm{F}}\right)+\mathrm{t}_{\mathrm{F}}-\mathrm{C}\right) \cdot \mathrm{Q}\left(\mathrm{P}_{\mathrm{f},}\left(\mathrm{t}_{\mathrm{F}}\right), \mathrm{P}_{\mathrm{f}}\right)\right] \\
& =\mu \pi_{\mathrm{N}}+(1-\mu) \pi_{\mathrm{f}}
\end{aligned}
$$

and depends on the chosen level of the alleged dumping margin. However, the domestic firm must keep in mind that a sufficiently high announcement of $t_{F}$ will induce cooperation and could result in lower expected profits.

The decision by the domestic firm is illustrated in Figure 3. The horizontal axis represents the dumping margin alleged by the domestic firm while the vertical axis measures domestic profits. As noted above, $\mathrm{E}_{\gamma}\left(\pi_{\text {coop }}\right)$ is independent of $\mathrm{t}_{\mathrm{F}}$ ( since $\pi_{\mathrm{N}}$ and $\pi_{\mathrm{A}}$ are invariant to $\left.t_{F}\right)$ so that it is a horizontal line in the graph. Profits under non-cooperation $\left(E_{\mu}\left[\pi_{N C}\right]\right)$ will increase as $t_{\mathrm{F}}$ rises, that is, domestic profits will rise unambiguously if foreign prices are forced up as tariffs on foreign goods increase. However, any tariff equal to or greater than $\mathrm{T}$ (the prohibitive tariff) will result in expected domestic profits equal to:

$$
\mathrm{E}_{\mu}\left[\pi_{\mathrm{NC}}(\mathrm{T})\right]=\mu \pi_{\mathrm{N}}+(1-\mu) \pi_{\mathrm{M}}
$$

where $\pi_{\mathrm{M}}$ denotes the monopoly level of domestic profits.

Define $\mathrm{t}_{\mathrm{BE}}$ as the announced dumping margin such that domestic profits are equal in the two paths $\left(\mathrm{E}_{\gamma}\left[\pi_{\text {coop }}\right]=\mathrm{E}_{\mu}\left[\pi_{\mathrm{NC}}\right]\right)$. To the right of $\mathrm{t}_{\mathrm{BE}}$ in Figure 3 , the domestic firm would prefer non-cooperation and to the left, a cooperative outcome. The preferred outcomes for the domestic firm are therefore represented by the bold line in Figure 3.

The final level of profits depend on the decisions taken by the foreign firm and the compliance costs chosen by the authority so that the domestic firm must take into account the foreign firm incentives to cooperate before announcing its alleged dumping margin. As 
discussed above, for any $t_{F}>t^{*}{ }_{B E}(K)$ the foreign firm will cooperate and for $t_{F}<t^{*}{ }_{B E}(K)$, the foreign firm will not cooperate.

Finally, it is critical to note that the breakeven tariff for the two paths generally will not correspond for the domestic and foreign firms, that is, $t_{\mathrm{BE}}$ need not equal $\mathrm{t}^{*}{ }_{\mathrm{BE}}(\mathrm{K})$. The reason is simple. Since the firms are imperfect substitutes and face differential taxation in the form of import duties, there is no reason to believe that these two breakeven tariffs will be equal. This leaves open the critical possibility that there may be some combinations of $t_{F}$ and $t_{A}$ where the domestic firm would like to see non-cooperation and the foreign firm would prefer to cooperate with the domestic investigation. These divergent incentives put some limits on the domestic firm's ability to manipulate the system, as we will see below.

Suppose that the compliance costs announced by the administering authority (represented by $\mathrm{K}_{1}$ in Figure 3) are relatively low so that $\mathrm{t}_{\mathrm{BE}}\left(\mathrm{K}_{1}\right)<\mathrm{t}_{\mathrm{BE}}$. If the domestic firm announces a dumping allegation such $\mathrm{t}_{\mathrm{F}}<\mathrm{t}^{*}{ }_{\mathrm{BE}}\left(\mathrm{K}_{1}\right)$, then the foreign firm will not cooperate yielding a domestic profit of $\mathrm{E}_{\gamma}\left[\pi_{\mathrm{NC}}\right]$ even though the domestic firm would prefer cooperation. Thus, the domestic firm has an incentive to allege a higher level of dumping. For any $t_{F}>$ $\mathrm{t}_{\mathrm{BE}}\left(\mathrm{K}_{1}\right)$, the foreign firm will cooperate, resulting in a profit level of $\mathrm{E}_{\gamma}\left(\pi_{\mathrm{COOP}}\right)$. In other words, if $\mathrm{t}_{\mathrm{BE}}^{*}\left(\mathrm{~K}_{1}\right)<\mathrm{t}_{\mathrm{BE}}$ the domestic firm should make an announcement which results in cooperation. Suppose instead that compliance costs are relatively high (represented by $\mathrm{K}_{2}$ in Figure 3 ) so that $\mathrm{t}_{\mathrm{BE}}<\mathrm{t}^{*}{ }_{\mathrm{BE}}\left(\mathrm{K}_{2}\right)$. In this event, the high compliance costs make the threat of a high dumping allegation especially onerous for the foreign firm. For any $t_{\mathrm{F}}>\mathrm{t}^{*}{ }_{\mathrm{BE}}\left(\mathrm{K}_{2}\right)$, the foreign firm will cooperate, resulting in a profit level of $\mathrm{E}_{\gamma}\left(\pi_{\mathrm{COOP}}\right)$ which is dominated by the non-cooperative 
profit level. Thus the domestic firm should announce a price as close as possible to ${ }^{*}{ }_{\mathrm{BE}}\left(\mathrm{K}_{2}\right)$ but not to exceed it so that the foreign firm will not cooperate.

We can summarize these outcomes in the following proposition:

\section{Proposition 1:}

A) If $\mathrm{t}_{\mathrm{BE}}<\mathrm{t}^{*}{ }_{\mathrm{BE}}(\mathrm{K})<\mathrm{T}$, then the domestic firm should announce a dumping margin allegation equal to $\mathrm{t}_{\mathrm{F}}=\mathrm{t}_{\mathrm{BE}}(\mathrm{K})-\varepsilon$, where $\varepsilon>0$ is arbitrarily small. The foreign firm will not cooperate and the domestic firm will obtain the non-cooperative level of profits $\mathrm{E}_{\mu}\left[\pi_{\mathrm{NC}}\left(\mathrm{t}_{\mathrm{F}}\right)\right]$ associated with $\mathrm{t}_{\mathrm{F}}=\mathrm{t}^{*}{ }_{\mathrm{BE}}(\mathrm{K})-\varepsilon$.

B) If $t_{B E}>t^{*}{ }_{B E}(K)$, then for any $t_{F}>t^{*}{ }_{B E}(K)$, the foreign firm will cooperate and the relevant domestic profit will be $\mathrm{E}_{\gamma}\left[\pi_{\mathrm{COOP}}\right]$.

We can see that the preferred outcome of the domestic firm depends critically on the relationship between the expected price if the foreign firm cooperates with the investigation and the breakeven facts-available announcement. This makes clear that the domestic firm's interests are not always served by forcing the foreign firm to not cooperate and be subject to the factsavailable cost allegation. The domestic firm's interests will depend on the level of the compliance costs. Consequently, the administering authority's determination of compliance costs will be critical in determining what strategy the domestic firm would prefer to follow. It is to that decision that we now turn.

\section{Stage 1: Administering authority decision}

We assume that the administering authority for this part of the antidumping process has only one decision variable----compliance costs faced by the foreign firm. As should be clear from above, the authority's choice of $\mathrm{K}$ will determine the relative attractiveness of cooperation 
and non-cooperation for both the domestic and foreign firm. Therefore, we continue to assume for simplicity that $\mu$ and $\gamma$, as well as the cooperative antidumping duty $\left(t_{A}\right)$ remain exogenous.

Two different types of authority behavior will be analyzed. We first assume that the authority does not choose K strategically. Secondly, we assume that the authority can vary K for each individual petition in order to maximize its objective function. Two subtypes for strategic behavior are analyzed. The first assumes that the authority is indifferent to domestic consumer effects. The second allows both consumer and producer effects to be considered by the authority.

\section{V. a. Model 1: Non-strategic Authority Behavior}

Suppose that the authority cannot alter the level of compliance costs. Nonetheless, this fixed $\mathrm{K}$ would result in situations where a specific foreign firm may or may not cooperate. Suppose for example that the unchanging compliance cost is given $\mathrm{K}=\mathrm{K}_{1}$ in Figure 3 . As we discussed above, in this particular case we would have $\mathrm{t}^{*}{ }_{\mathrm{BE}}(\mathrm{K})<\mathrm{t}_{\mathrm{BE}}$ so that the domestic firm would announce a facts-available tariff which would induce cooperation. But it is entirely possible that for another industry and a different foreign and domestic firm, this same level of $\mathrm{K}$ might result in a situation where $\mathrm{t}^{*}{ }_{\mathrm{BE}}(\mathrm{K})>\mathrm{t}_{\mathrm{BE}}$. . This might happen if $\mathrm{E}_{\gamma}\left(\pi_{\mathrm{NC}}\right)$ were steeper for this other firm. This domestic firm, facing the same compliance costs, would make an announcement that yielded non-cooperation by the foreign firm. Which situation pertains depends on the underlying market parameters facing the firms.

With non-strategic behavior, we therefore would expect that compliance costs would be non-varying but we would observe both cooperation and non-cooperation by different foreign firms. We might witness such a scenario if $\mathrm{K}$ is determined exogenously by legislation or if the 
authority's decision is carefully monitored by a judicial process with an eye towards standardized treatment of foreign firms.

\section{V. b. Strategic Authority Behavior}

Assume instead that the authority has complete freedom when choosing compliance costs. We assume only that $\mathrm{K}$ is strictly positive, i.e., the administering authority must "charge" foreign firms at least a nominal amount to conduct the investigation.

In the most general case, the administering authority will maximize a weighted average of domestic consumer surplus, domestic producer surplus, and its own costs of conducting a cooperative investigation:

$$
\begin{aligned}
& \mathrm{W}\left(\mathrm{P}(\mathrm{K}), \mathrm{P}^{*}(\mathrm{~K}), \mathrm{K}\right)=\alpha_{1} \mathrm{CS}(\mathrm{K})+\alpha_{2} \mathrm{PS}(\mathrm{K})+\alpha_{3} \mathrm{~g}(\mathrm{~K}) \\
& \text { s.t. For } \mathrm{t}_{\mathrm{BE}}<\mathrm{t}^{*}{ }_{\mathrm{BE}}(\mathrm{K}) \text {, then } \mathrm{t}_{\mathrm{F}}=\mathrm{t}^{*}{ }_{\mathrm{BE}}(\mathrm{K})-\varepsilon \text { and domestic profit } \\
& \text { equals } \mathrm{E}_{\mu}\left[\pi_{\mathrm{NC}}\left(\mathrm{t}_{\mathrm{F}}\right)\right] \text {; foreign firms do not cooperate } \\
& \text { and } \\
& \text { For } \mathrm{t}^{*}{ }_{\mathrm{BE}}(\mathrm{K})<\mathrm{t}_{\mathrm{BE}} \text {, then } \mathrm{t}_{\mathrm{F}}>\mathrm{t}^{*}{ }_{\mathrm{BE}}(\mathrm{K}) \text { and domestic profit equals } \\
& \mathrm{E}_{\gamma}\left[\pi_{\text {coop }}\right] \text {; foreign firms cooperate }
\end{aligned}
$$

The administering authority's utility function is a non-decreasing function of rising producer and consumer surplus. The function $\mathrm{g}($.$) represents the disutility that the administering$ authority faces if it must devote time and resources to conduct an investigation. We assume that if foreign firm compliance costs rise, then compliance efforts by the authority also increase. 
Thus, we have that $\operatorname{dg}(\mathrm{K}) / \mathrm{dK}<0$ for any outcome when there is cooperation. ${ }^{16}$ With noncooperation, we assume for simplicity that its utility is unaffected by increasing the compliance cost burden on the foreign firm, i.e., $\mathrm{dg}(\mathrm{K}) / \mathrm{dK}=0$ for any non-cooperative outcome.

The constraints arise because the authority must solved the problem taking into account the decisions made by the domestic and foreign firms in latter stages of the game.

The impact of a change in K will have differing effects on the administering authority's objective function according to whether the foreign firm decides to cooperate. With no cooperation, we know from Proposition 1 that increasing compliance costs will allow the domestic firm to raise its facts-available announcement so that the domestic price rises, hurting domestic consumers but helping domestic producers:

$$
\mathrm{dCS} / \mathrm{dK}<0 \text { and } \mathrm{dPS} / \mathrm{dK}>0 \quad \forall \mathrm{K} \text { such that } \mathrm{t}_{\mathrm{BE}}<\mathrm{t}^{*}{ }_{\mathrm{BE}}(\mathrm{K})
$$

If the compliance costs are such that the foreign firm does cooperate, then we know from Proposition 1 that the relevant domestic profit will be $E_{\gamma}\left(\pi_{\text {coop }}\right)$, regardless of the level of compliance costs chosen by the authority. We therefore have the following:

$$
\mathrm{dCS} / \mathrm{dK}=0 \text { and } \mathrm{dPS} / \mathrm{dK}=0 \quad \forall \mathrm{K} \text { such that } \mathrm{t}_{\mathrm{BE}}>\mathrm{t}^{*}{ }_{\mathrm{BE}}(\mathrm{K})
$$

\section{Model 2: Consumer-indifferent Authority}

${ }^{16}$ One could assume alternatively that the authority uses investigations to justify its budgets as in Niskanen (1971) so that $\mathrm{dg} / \mathrm{dK}>0$. While potentially valid, we do not pursue this particular scenario in this paper. 
Suppose first that the administering authority is indifferent to the costs imposed on domestic consumers, i.e., $\alpha_{1}=0$.

In this case, the administering authority will achieve its maximum when the domestic price and profits are at the highest possible level, i.e., at the prohibitive tariff $\mathrm{T}$ where all imports are eliminated if the domestic firm wins the case. Let $\mathrm{K}^{+}$be the minimum level of compliance costs such that $\mathrm{E}_{\mu}\left[\pi{ }_{\mathrm{NC}}(\mathrm{T})\right]=\mathrm{E}_{\gamma}\left[\pi *_{\text {COOP }}\left(\mathrm{K}^{+}\right)\right]$. At this point, the foreign firm is indifferent between facing the prohibitive tariff with non-cooperation or the compliance cost $\mathrm{K}^{+}$with cooperation. In Figure 2, this point would be illustrated by shifting $\mathrm{E}_{\gamma}\left[\pi *_{\mathrm{COOP}}\right]$ down to the point where it just intersects the vertical section of $\mathrm{E}_{\mu}\left[\pi *_{\mathrm{NC}}\right]$ at the prohibitive tariff. At this point, the breakeven tariff allegation for the foreign firm equals $\mathrm{T}$. If the authority chooses $\mathrm{K}^{+}+\sigma$, where

$\sigma$ is an arbitrarily small positive number, then we would have $\mathrm{E}_{\mu}\left[\pi *_{\mathrm{NC}}(\mathrm{T})\right]>\mathrm{E}_{\gamma}\left[\pi *_{\mathrm{COOP}}\left(\mathrm{K}^{+}+\sigma\right.\right.$ )$]$.

The domestic firm could announce a facts-available tariff allegation equal to the prohibitive tariff: $\mathrm{t}_{\mathrm{F}}^{+}=\mathrm{T}$. The foreign firm will decide not to cooperate, the authority will avoid the disutility of conducting an investigation, and expected domestic profits will be: $\mathrm{E}_{\mu}\left[\pi_{\mathrm{NC}}(\mathrm{T})\right]$. If the domestic firm wins the petition, then the prohibitive tariff is imposed.

To summarize, with a consumer-indifferent authority, we should see high compliance costs, no cooperation, no investigations actually conducted, as well as prohibitive tariffs and monopoly profits when the domestic firm wins.

\section{Model 3: Consumer-caring Authority}

Suppose that consumer welfare does enter the administering authority's objective function. Form the Lagrangian for the solution when there is non-cooperation by the foreign 
firm:

$$
\mathrm{L}=\alpha_{1} \operatorname{CS}(\mathrm{K})+\alpha_{2} \operatorname{PS}(\mathrm{K})+\alpha_{3} \mathrm{~g}(\mathrm{~K})+\lambda\left[\mathrm{t}_{\mathrm{F}}-\mathrm{t}^{*}{ }_{\mathrm{BE}}(\mathrm{K})-\varepsilon\right]
$$

The familiar solution, denoted as $\mathrm{K}^{*}$, to the unconstrained problem with non-cooperation (since $\operatorname{dg}(\mathrm{K}) / \mathrm{dK}=0$ with no investigation) will be defined implicitly by the following:

$$
\alpha_{1} \mathrm{dCS}(\mathrm{K}) / \mathrm{dK}+\alpha_{2} \mathrm{dPS}(\mathrm{K}) / \mathrm{dK}-\lambda d \mathrm{t}^{*}{ }_{\mathrm{BE}}(\mathrm{K}) / \mathrm{dK}=0
$$

that is, $\mathrm{K}$ will be increased to the point where the weighted marginal effects on consumers and producer surplus just equals the change in the breakeven tariff for the foreign firm. This outcome would be at a point like $\mathrm{t}\left(\mathrm{K}^{*}{ }_{\mathrm{NC}}\right)$ in Figure 4 and the resulting domestic profit of $\mathrm{E}_{\mu}\left[\pi_{\mathrm{NC}}\left(\mathrm{t}\left(\mathrm{K}^{*}{ }_{\mathrm{NC}}\right)-\varepsilon\right)\right]$. Implemented tariffs will be lower than the prohibitive level $\mathrm{T}$.

Note that the optimal compliance cost above is a negative function of $\alpha_{1}$. This means that for a sufficiently large weight on consumer effects, then $\mathrm{t}\left(\mathrm{K}^{*}\right)$ could be less than $\mathrm{t}_{\mathrm{BE}}$. In this case, the foreign firm cooperates and the relevant domestic profit is $\mathrm{E}_{\gamma}\left(\pi_{\text {coop }}\right)$. We know that with cooperation

$$
\mathrm{dCS}(\mathrm{K}) / \mathrm{dK}=\mathrm{d} \operatorname{PS}(\mathrm{K}) / \mathrm{dK}=0
$$

The administering authority, because $\mathrm{dg} / \mathrm{dK}<0$, will set the compliance cost as close to zero as possible to conduct the investigation. In terms of Figure 4, the optimal solution to the problem above would at a point like $\mathrm{K}^{*}$.

In short, if the authority values consumer welfare and dislikes conducting investigations, 
then we should expect varying compliance costs. When there is cooperation, then compliance costs should be very low. In addition, some foreign firms will cooperate while others will not. Prohibitive levels of tariffs will not occur for successful petitions.

These results of these two types of strategic domestic authority behavior can be summarized by the following:

\section{Proposition 2:}

\section{Model 2: Consumer-indifferent authority}

For $\alpha_{1}=0$, a non-cooperative outcome will always pertain when the authority chooses $\mathrm{K}$ strategically. Compliance costs will equal $\mathrm{K}^{+}+\sigma$, with $\sigma>0$ and where $\mathrm{K}^{+}$solves $\mathrm{E}_{\mu}\left[\pi *_{\mathrm{NC}}(\mathrm{T})\right]=\mathrm{E}_{\gamma}\left[\pi *_{\mathrm{COOP}}\left(\mathrm{K}^{+}\right)\right]$. The domestic firm announces $\mathrm{t}_{\mathrm{F}}^{+}=\mathrm{T}$ (the prohibitive tariff). Expected domestic profit is: $E_{\mu}\left[\pi_{N C}(T)\right]=\mu \pi_{N}+(1-\mu) \pi_{M}$ and expected foreign profit equals: $E_{\mu}\left[\pi *_{N C}(T)\right]=\mu \pi *_{N}$.

\section{Model 3: Consumer-caring authority}

a) For $\alpha_{1}>0$ and $t\left(\mathrm{~K}^{*}\right)>\mathrm{t}_{\mathrm{BE}}$, a non-cooperative outcome will occur. Domestic profits will equal $\mathrm{E}_{\mu}\left[\pi_{\mathrm{NC}}\left(\mathrm{t}_{\mathrm{f}}^{*}\right)\right]$ where $\mathrm{t}_{\mathrm{F}}^{*}=\mathrm{t}_{\mathrm{BE}}\left(\mathrm{K}^{*}\right)-\varepsilon<\mathrm{T}$ and where $\mathrm{K}^{*}\left(<\mathrm{K}^{+}\right)$ solves expression (13). Expected foreign profit equals: $\mathrm{E}_{\mu}\left[\pi *_{\mathrm{NC}}\left(\mathrm{t}_{\mathrm{F}}^{*}\right)\right]>\mu \pi *_{\mathrm{N}}$.

b) For $\alpha_{1}>0$ and $t_{\mathrm{BE}}>\mathrm{t}\left(\mathrm{K}^{*}\right)$, the foreign firm cooperates and the domestic profit equals $\mathrm{E}_{\gamma}\left(\pi_{\mathrm{COOP}}\right)$ and $\mathrm{K}$ will be arbitrarily small. Expected foreign profit equals: $\mathrm{E}_{\mu}\left[\pi *_{\mathrm{COOP}}\right]>\mu \pi *_{\mathrm{N}}$.

When consumer effects are ignored by the authority, prices and foreign compliance costs are at the highest possible level. Even if consumers "matter," it is entirely possible that the administering authority's choice of compliance costs will force foreign firms into noncooperation with resulting higher prices for domestic consumers. These results also indicate that one cannot use the fact that one observes the use of "facts-available" in practice that the 
authority does not care about consumer effects of protection.

It is worth examining how changes in a few underlying parameters will change the likelihood of a cooperative outcome, taking into account the incentives of all players.

Suppose for example that the probability of an affirmative dumping decision in the cooperative investigation is increased (i.e., $\gamma$ falls). In Figure 3, there will a shift upwards in $\mathrm{E}_{\gamma}\left(\pi_{\text {coop }}\right)$ since $\pi_{\mathrm{N}}<\pi_{\mathrm{A}}$. This will increase the level of alleged dumping margin which would make the domestic firm indifferent between the two options, i.e., $t_{\mathrm{BE}}$ will rise. At the same time, the foreign firm will find that cooperation will be less attractive (i.e.., $\mathrm{dF} / \mathrm{d} \gamma>0$ ). This will mean that the "facts-available" threat would have to be even larger than before to induce cooperation from the foreign firm, i.e., $t^{*}{ }_{\mathrm{BE}}(\mathrm{K})$ would rise. The final effects of whether or not cooperation would less likely to occur would depend on the relative sizes of the two effects.

Assume for example that initially there was non-cooperation (i.e., $\mathrm{t}_{\mathrm{BE}}<\mathrm{t}^{*}{ }_{\mathrm{BE}}(\mathrm{K})$ ). If the increase in $t_{\mathrm{BE}}$ was large relative to the increase in $\mathrm{t}_{\mathrm{BE}}(\mathrm{K})$, a change in the behavior of the foreign firm could be observed. The relative effects will, of course, depend on the nature of the underlying profit functions of both firms. It is possible that the resulting effect would be that $t_{\mathrm{BE}}>\mathrm{t}_{\mathrm{BE}}(\mathrm{K})$, so that a cooperative outcome would occur. Oddly, making an affirmative antidumping decision under cooperation more likely actually could increase the chances that the foreign firm will choose to pursue the cooperative strategy. Not surprisingly, domestic profits will rise with the decrease in $\gamma$ regardless of the decision taken by the foreign firm; either the domestic firm is allowed to move up the $\mathrm{E}_{\mu}\left[\pi_{\mathrm{NC}}\right]$ schedule in Figure 3 (if non-cooperation continues) or shifts up to the new domestic expected profit scheduled associated with the decreased chance of losing an antidumping petition. 
The following table summarizes the outcomes for different authority behavior.

\begin{tabular}{|l|c|c|c|}
\hline \multicolumn{1}{|c|}{ Authority Behavior } & $\begin{array}{c}\text { Compliance } \\
\text { Cost }\end{array}$ & $\begin{array}{c}\text { Frequency of } \\
\text { Foreign Cooperation }\end{array}$ & Tariff \\
\hline Model 1: Non-strategic & constant & $<100 \%$ & varying \\
\hline Model 2: Strategic (consumer-indifferent) & constant & $0 \%$ & prohibitive \\
\hline Model 3: Strategic (consumer-caring) & varying & $<100 \%$ & varying \\
\hline
\end{tabular}

\section{Conclusion}

This paper has provided some tentative conclusions to an area ignored in the antidumping literature in economics. In particular, we consider the incentives for foreign firms to cooperate in antidumping investigations when they face the possibility that an administering authority can use allegations by the domestic petitioner when setting antidumping duties. The need for study in this area is evident given the very high margins which sometimes arise in US antidumping cases when so-called "facts available" are used by the Department of Commerce.

We set out to answer a number of questions. Most importantly, why do foreign firms sometimes not cooperate in antidumping investigations given the clear authority for governments to counter with punitive tariffs? In addition, we wanted to explore whether domestic firm would always allege prohibitive tariffs, given the possibility that domestic authority might use these allegations on non-cooperative firms. Finally, what are the domestic authority's motivations and strategies when setting compliance costs.

Within the framework introduced here, we find that foreign firms have ambiguous and conflicting incentives concerning possible cooperation. On the one hand, high compliance costs reduce the attractiveness of pursuing a "cooperative" antidumping path but a decision to forgo cooperation means that the "stick" of facts-available margins may be placed on their imports. 
We find that a foreign firm may choose not cooperate, even if is certain to win its case, as long as compliance costs are positive. This might be particularly problematic for small firms where compliance costs are high relative to any expected benefits from cooperation. In general, we certainly can say that foreign firms who do not cooperate may have nothing "to hide." Instead, they may simply be responding to the incentives presented by two possible paths of antidumping litigation.

We have also shown that for some values of compliance costs, a domestic firm would rather face a cooperating foreign firm while for others it would rather force the foreign firm to face the "facts-available" dumping margin. We cannot say that it is always in the domestic firm's interests to allege extremely high dumping margins by its foreign competitors, as long as the foreign firm has the option of cooperating with the domestic investigation. Certainly the presence of a path of possible cooperation limits a domestic firm's ability to completely manipulate the antidumping process through allegations of very high foreign costs.

But the most important results are obtained when the decisions of the domestic authority are modeled. We find three distinct patterns of tariffs, compliance costs, and degree of foreign competition. In Model 1, if the domestic authority cannot or does not want to vary compliance costs, perhaps because of legislative or judicial constraints, we find that there will be not be cooperation from all foreign firms, but with higher (lower) duties for non-cooperating (cooperating) firms. If instead the authority has the freedom to set compliance costs, the outcomes will depend critically on the degree to which consumer interests enter into its objective function. If the authority is indifferent to consumer losses (as in Model 2), we find that compliance costs will be set so high that there will never be cooperation and domestic firms' 
allegations of dumping margins will lead to prohibitive tariffs. If the authority does care about consumer effects (as in Model 3), then we will see non-prohibitive tariffs but compliance costs will vary greatly----extremely low costs when foreign firms cooperate and higher compliance costs when firms do not cooperate.

In principle, one should be able to look at the data to ascertain which of these predictions best fit actual practice. In the US for example, we find that facts-available information is used often but not exclusively. This would suggest that either Model 1 (non-strategic behavior) or Model 3 (consumer-sensitive) scenario. In principle, one should be able to distinguish between Models 1 and 3 by considering actual compliance costs. If they vary non-trivially across cases, then there is support for Model 3; if they remain unchanged, then the DOC may simply be precluded by judicial review from acting strategically. Unfortunately, it is very difficult to collect useful data on compliance costs. Nonetheless, this may be a useful exercise for later research.

Model 3 as a possibility may surprise observers familiar with complaints about alleged DOC bias in favor of domestic petitioners in antidumping cases. The patterns predicted in the model are, nonetheless, not consistent with a world in which the DOC arbitrarily sets compliance costs to benefit domestic firms so that some of the DOC's critics accusations may be unfounded.

Certainly this model abstract from many complications. Modifications would include making fully endogenous the probability of antidumping success and the level of tariff imposed in the antidumping petition so the entire government's problem is solved. But as argued above, varying these "parameters" may alter the particular profit levels facing the domestic and foreign firms but they would not change the basic problem that domestic firms make dumping 
allegations in a world where the foreign firm might respond by cooperating. One might also design an asymmetric information framework wherein the domestic authority provides an incentive compatible mechanism to induce truth-telling by the foreign firm. Of course, such a mechanism should be credible so that one would always see cooperation. Nonetheless, this research takes a first step towards building "facts-available" incentives into a model of antidumping procedures. 


\section{References}

Antidumping Agreement, in The Uruguay Round of Multilateral Trade Negotiations: General Agreement on Tariffs and Trade, Washington, D.C.: US Government Printing Office, 1994

Baldwin, Robert E. and Michael O. Moore, "Administration of the Unfair Trade Laws by the Department of Commerce: A Political Economy Analysis," in R. Boltuck and R. Litan (eds.), 'Down in the Dumps'- Administration of U.S. Trade Remedy Law, Washington, DC: Brookings Institution, 1991.

Brander and Krugman, "Reciprocal Dumping" Journal of International Economics, vol. 15, pp. 313-324, November 1983.

Devault, James M., "Economics and the International Trade Commission," Southern Economic Journal; vol. 60 no. 2 pp. 463-78. October 1993.

Ethier, Wilfred, “Dumping” Journal of Political Economy, vol 90., pp. 487-506, 1982.

Finger, J. Michael and Nellie Artis (Eds.), Antidumping : How It Works and Who Gets Hurt, Ann Arbor: University of Michigan Press, 1993.

Finger, J. Michael, H. Keith Hall, and Douglas Nelson, "The Political Economy of Administered Protection,"American Economic Review, June 1982, pp. 452-66.

Gallaway, Michael P.; Blonigen, Bruce A.; Flynn, Joseph E, "Welfare Costs of the U.S. Antidumping and Countervailing Duty Laws," Journal of International Economics vol 49, no. 2 December 1999.

Hartigan, James C., "Endogenous Obfuscation in Injury Investigations” mimeo, 2000a.

Hartigan, James C, “Design on an Antidumping Law," Journal of Economic Integration, vol 15, no. 4, pp. 654-668. $2000 \mathrm{~b}$.

Kohler, Philippe and Michael O. Moore "Injury-based Protection with Auditing under Imperfect Information," with Philippe Kohler, Southern Economic Journal, 2001.

Liebman, Benjamin, "Sunset Reviews and ITC Commissioner Voting Behavior," University of Oregon, mimeo, 2001.

Mastel, Greg, Antidumping Laws and the US Economy, Armonk, New York: M.E. Sharpe, 1998. 
Messerlin, Patrick (1989), "The EC Antidumping Regulations: A First Economic Appraisal, 1980-1985, "Weltwirtschaftliches Archiv, 125(3), pp. 563-87.

Moore, Michael O. and Steven Suranovic, "Lobbying vs. Administered Protection: Endogenous Industry Choice and Welfare," (with Steven Suranovic), Journal of International Economics, vol. 32, pp. 289-303, 1992.

Moore, Michael O., "Rules or Politics?: An Empirical Analysis of ITC Antidumping Decisions," Economic Inquiry, vol. 30, pp. 446-466, July 1992.

Moore, Michael O., "Antidumping Reform in the US: A Faded Sunset” Journal of World Trade, vol. 33, no. 4, pp. 1-88, August 1999.

Murray, Tracy, "The Administration of the Antidumping Duty Law by the Department of Commerce," in R. Boltuck and R. Litan (eds.), 'Down in the Dumps'- Administration of U.S. Trade Remedy Law, Washington, DC: Brookings Institution, 1991.

Niskanen, William, Bureaucracy and Representative Government, Chicago: Aldine-Atherton, Inc., 1971.

Palmeter, N. David, (The Antidumping Law: A Legal and Administrative Nontariff Barrier," in R. Boltuck and R. Litan (eds.), 'Down in the Dumps'- Administration of U.S. Trade Remedy Law, Washington, DC: Brookings Institution, 1991.

Prusa, Thomas (1992), “Why are so Many Antidumping Petitions Withdrawn,” Journal of International Economics, 33, pp. 1-20.

Prusa, Thomas and Wendy Hansen, "The Economics and Politics of Trade Policy: An Empirical Analysis of ITC Decision Making," Review of International Economics., vol. 5 no. 2 pp. 230-45. May 1997.

Staiger, Robert and Frank Wolack, "The Effect of Import Source on the Determinants and Impacts of Antidumping Suit Activity," in Anne O. Krueger, ed.. The Political Economy of Trade Protection, Chicago and London: University of Chicago Press, 1996, pp. 85-93.

Stewart, Terrence, "Administration of the Antidumping Law: A Different Perspective," in R. Boltuck and R. Litan (eds.), 'Down in the Dumps'- Administration of U.S. Trade Remedy Law, Washington, DC: Brookings Institution, 1991. 


\section{Figure 1}

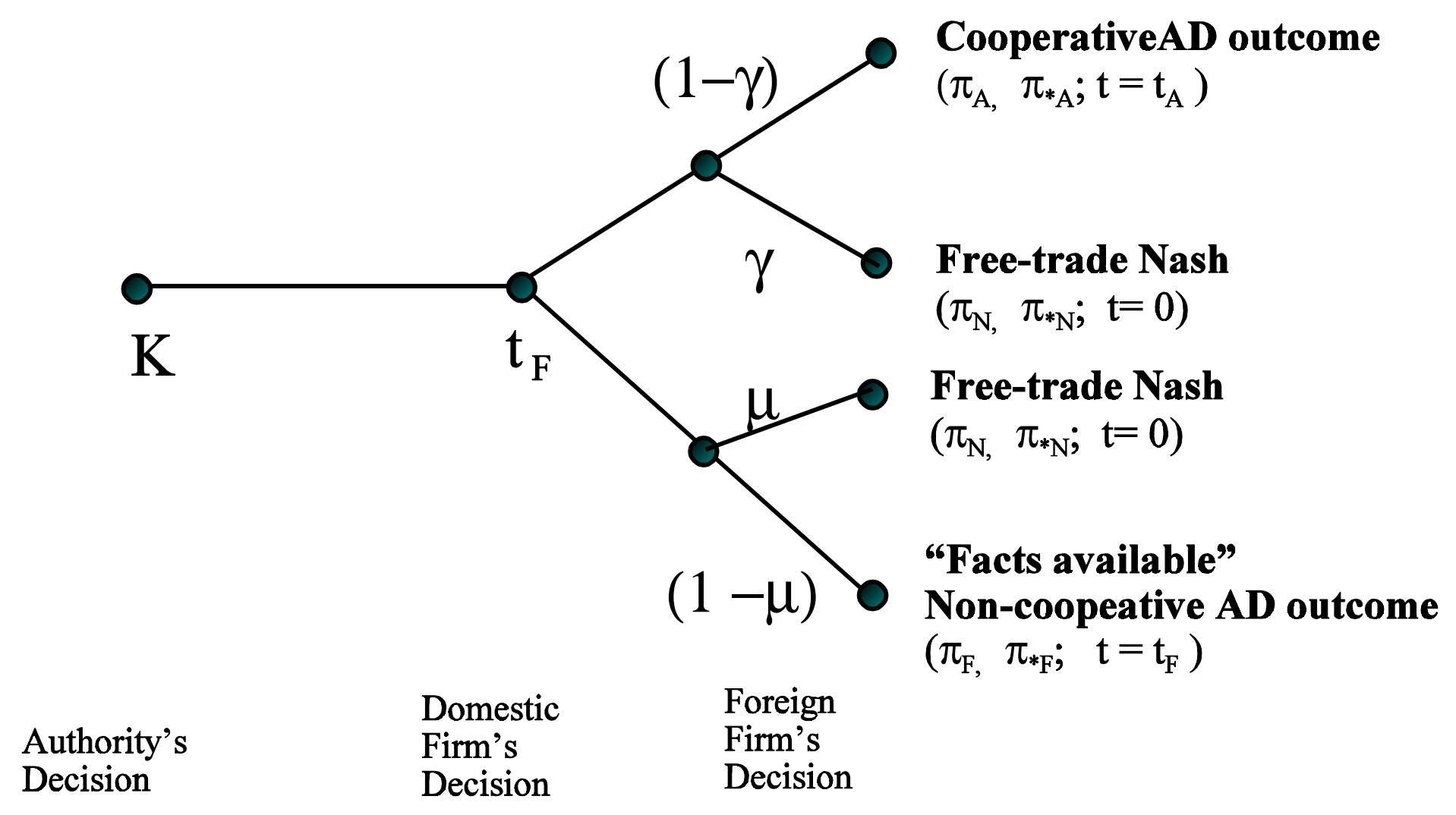


Figure 2

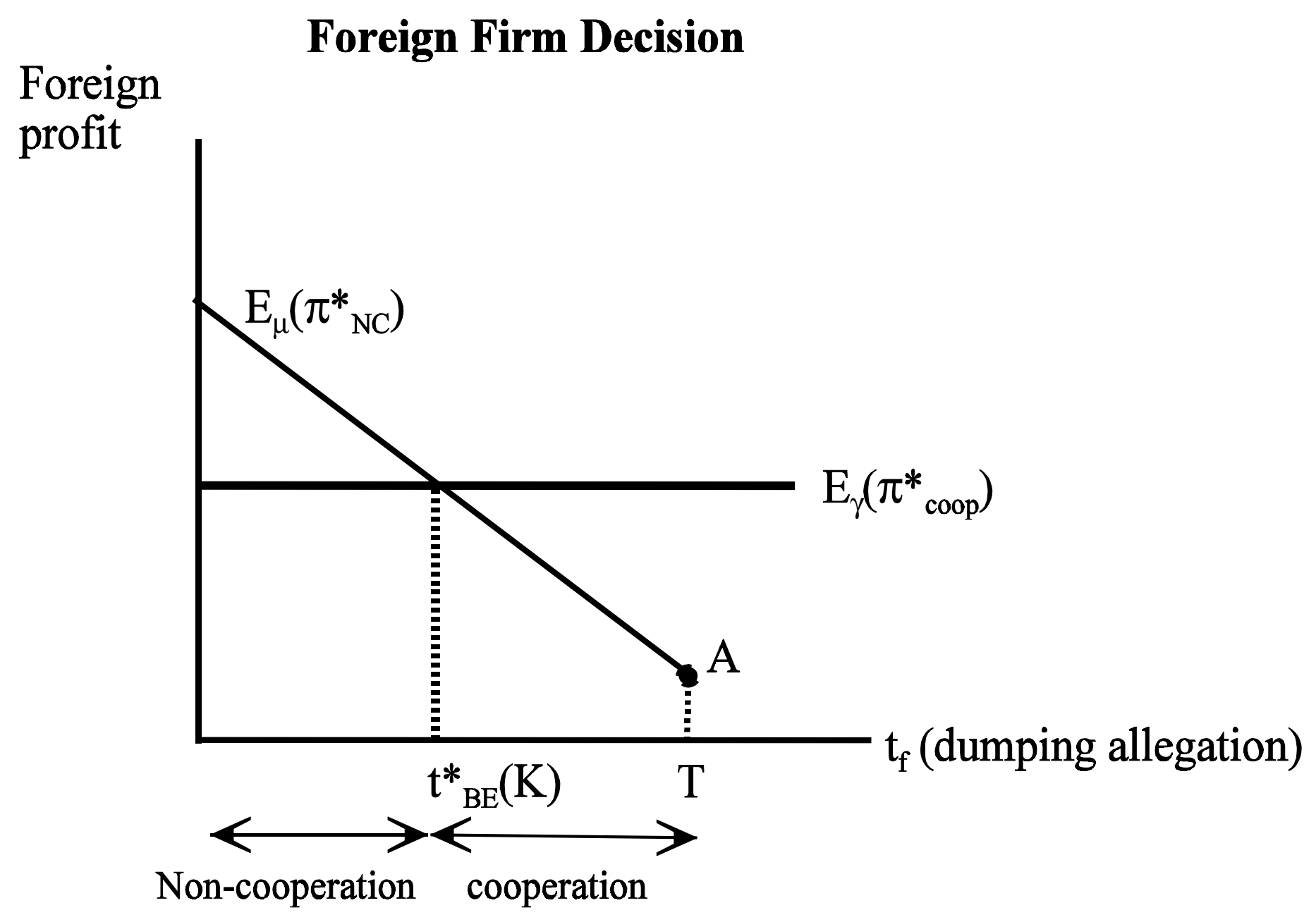


Figure 3

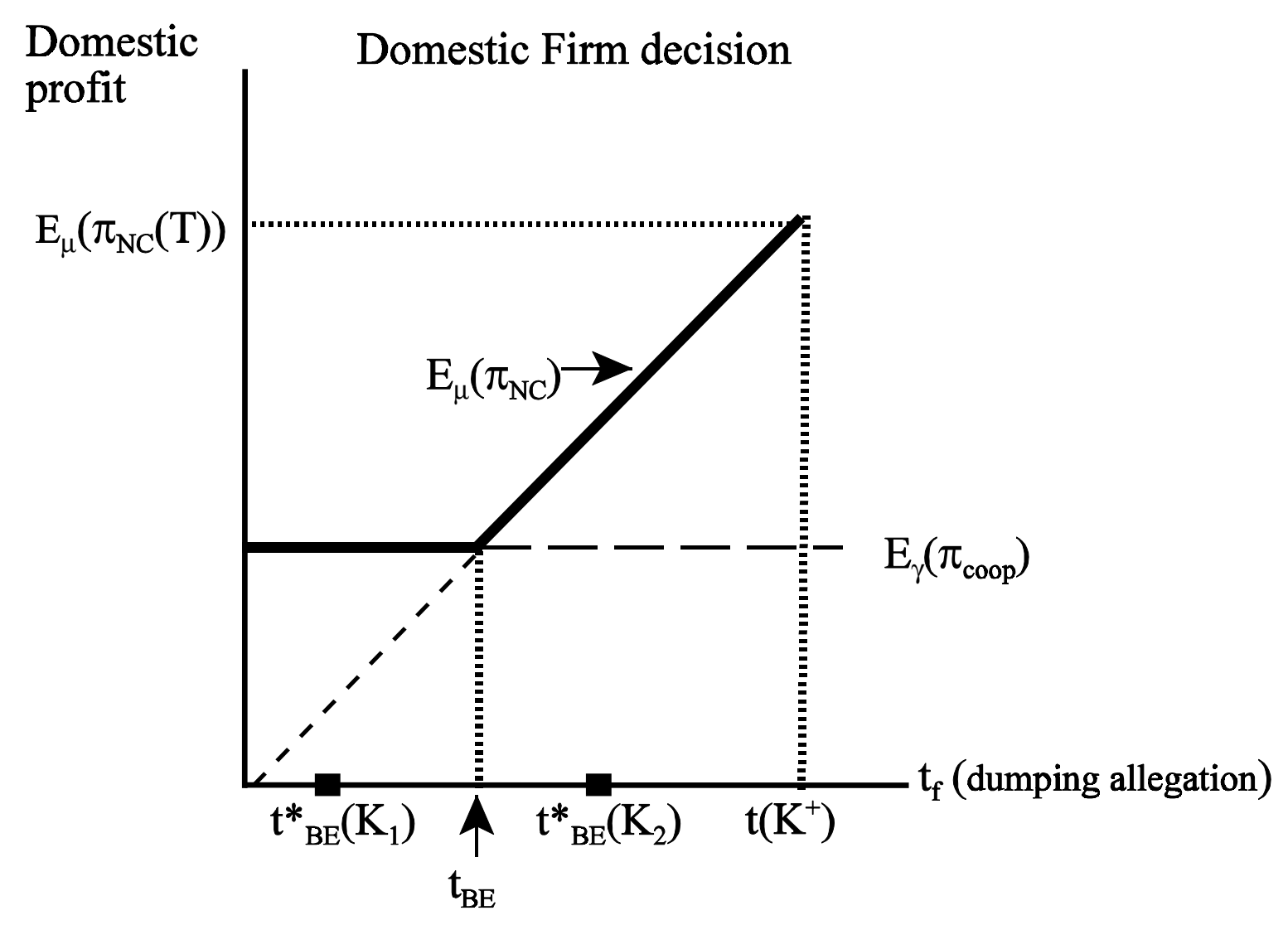


Figure 4

\section{Domestic Authority Decision}

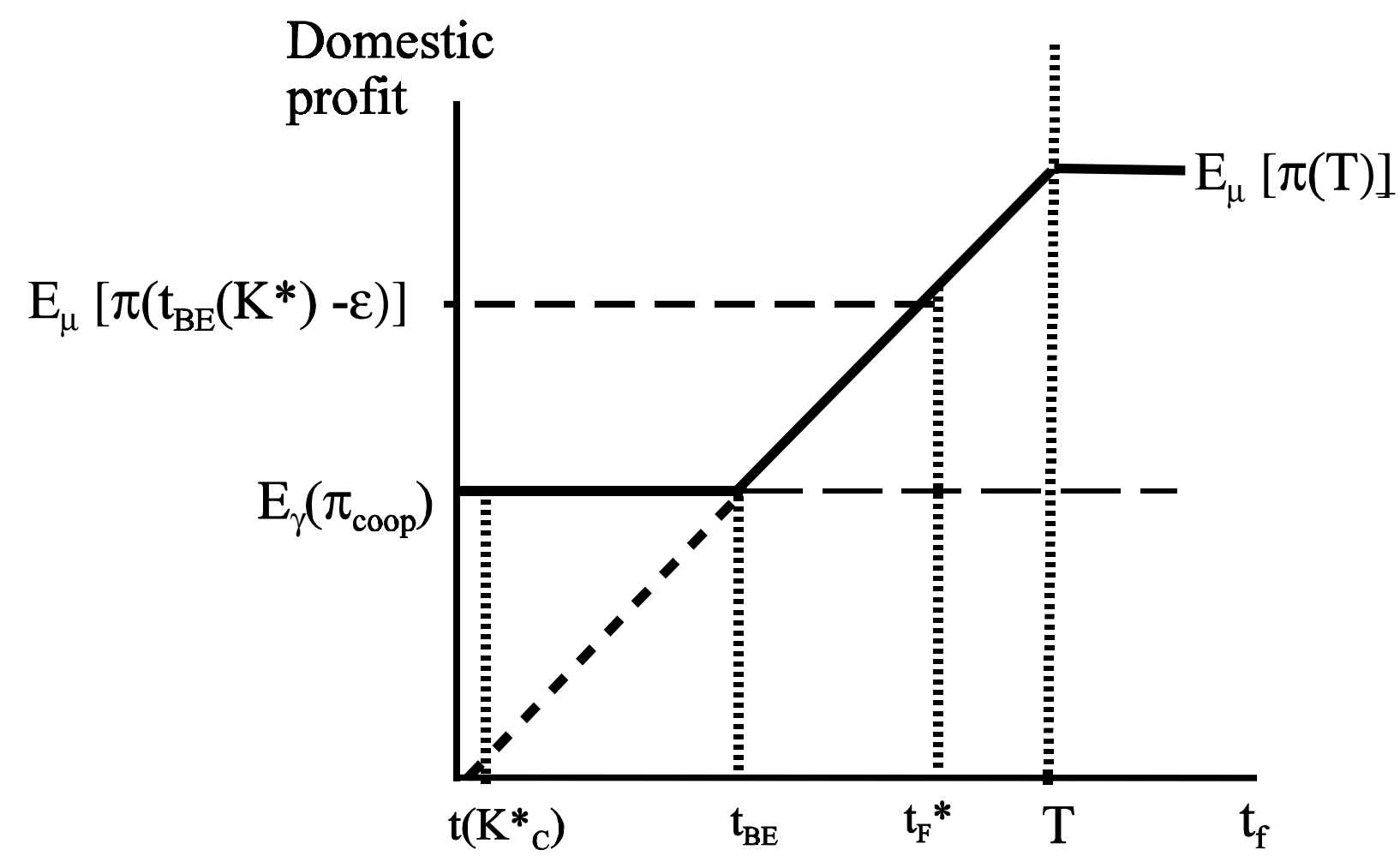

